\title{
Hubungan Asupan Asam Folat, Zink, dan Vitamin A Ibu Hamil Trimester III terhadap Berat Badan Lahir di Kabupaten Padang Pariaman
}

\author{
Wici Septiyeni ${ }^{1}$, Nur Indrawati Lipoeto ${ }^{2}$, Joserizal Serudji ${ }^{3}$
}

\begin{abstract}
Abstrak
Berat badan lahir merupakan salah satu indikator kesehatan bayi baru lahir. Berat badan lahir dipengaruhi oleh berbagai faktor yang salah satunya adalah mikronutrien seperti: asam folat, zink dan vitamin A yang disinyalir memiliki hubungan dengan berat badan lahir.Tujuan penelitian ini adalah menentukan hubungan antara asupan asam folat, seng, dan vitamin A terhadap berat badan lahir. Penelitian ini merupakan cross sectional study pada 59 ibu hamil di Kabupaten Padang Pariaman. Pengumpulan data dilakukan dengan wawancara dan pengukuran berat badan lahir. Analisis statistik yang digunakan adalah uji korelasi Spearman. Hasil penelitian ini yaitu rata-rata umur ibu hamil sebesar 26,5424 tahun. Rata-rata berat badan lahir 3181,36 gram dan rata-rata tinggi badan ibu adalah 153,8305 cm. Rata-rata konsumsi asam folat subjek penelitian adalah 341,9525 ug, zink 5,0727 mg dan vitamin A 688,9300 RE. Hasil analisis menunjukkan tidak terdapat hubungan yang bermakna antara asupan asam folat dan berat badan lahir $(p>0,05)$, asupan zink dan berat badan $(p>0,05)$ dan asupan vitamin $A$ dan berat badan lahir $(p>0,05)$.bKesimpulan penelitian ini adalah bahwa tidak ada hubungan antara asupan asam folat, zink dan vitamin $A$ ibu hamil trimester III terhadap berat badan lahir.
\end{abstract}

Kata kunci: asam folat, zink, vitamin A, berat badan lahir, Ibu hamil trimester III

\begin{abstract}
Birth weight is an indicator of the health of the newborn. Birth weight is influenced by various factors like micronutrients such as: folic acid, zinc and vitamin $A$ which allegedly had a relationship with birth weight. The objective of this study was to determine the relationship between the intake of folic acid, zinc, and vitamin A on birth weight. This study was a cross sectional study to 59 pregnant women in the district of Padang Pariaman. Data collection with interviews and birth weight measurements. Statistical analysis used the Spearman correlation test. The results of this study showed that the average maternal age of 26.5424 years and the average maternal height was $153.8305 \mathrm{~cm}$. Average birth weight $3181.36 \mathrm{~g}$. The average consumption of folic acid is $341.9525 \mathrm{ug}, 5.0727 \mathrm{mg}$ zinc and vitamin $A$ 688.9300 RE. Analysis result showed no significant association between the intake of folic acid and birth weight ( $p>$ 0.05), zinc intake and birth weight $(p>0.05)$ and intake of vitamin $A$ and birth weight $(p>0,05)$. The conclusion of this study is no relationship between the intake of folic acid, zinc and vitamin $A$ of third trimester pregnant women toward birth weight.
\end{abstract}

Keywords: folic acid, zinc, vitamin A, birth weight, third trimester pregnant women

Affiliasi penulis: 1. Pendidikan Dokter FK UNAND (Fakultas Kedokteran Universitas Andalas Padang), 2. Bagian Gizi FK UNAND, 3. Bagian Kebidanan FK UNAND/RSUP dr. M.Djamil Padang.

Korespondensi: Wici Septiyeni, email :

wici.septy@gmail.com,telp:081363716765

\section{PENDAHULUAN}

Asupan gizi yang baik selama kehamilan merupakan hal yang penting, yaitu dengan mengkonsumsi banyak makronutrien dan mikronutrien 
yang memberikan manfaat untuk memenuhi kebutuhan tambahan nutrisi selama kehamilan. ${ }^{1}$

Berat badan lahir merupakan salah satu indikator kesehatan bayi. ${ }^{2}$ Jenis berat badan lahir yang paling berisiko menimbulkan masalah pada bayi baru lahir adalah berat bayi yang < 2500 gram atau disebut dengan berat badan lahir rendah $(B B L R) .{ }^{2}$ Diantara kota/kabupaten di Sumatera Barat, kota/kabupaten Pariaman merupakan salah satu kota/kabupaten dengan prevalensi BBLR cukup tinggi yaitu sebesar $3,5 \%$ pada tahun $2007 .^{3}$

Berat badan lahir dipengaruhi oleh berbagai factor seperti: usia ibu hamil, penyakit saat kehamilan, jarak kehamilan, kadar hemoglobin, status sosial ekonomi yang nantinya juga akan mempengaruhi status gizi ibu hamil baik konsumsi makronutrien maupun mikronutrien. ${ }^{4}$

Pada periode trimester III gestasi 36 minggu tubuh janin mengalami pengendapan lemak subkutis sehingga tubuh menjadi lebih bulat. ${ }^{5}$ Status gizi ibu dipengaruhi oleh besaran asupan energi atau kalori, protein,karbohidrat, zat besi, asam folat, vitamin $A$, zink, kobalamin, vitamin $D$, yodium, kalsium serta zat gizi lainnya. ${ }^{4}$ Ada beberapa mikronutrien seperti zink, vitamin $A$, dan asam folat yang juga disinyalir memiliki hubungan dengan berat badan lahir. ${ }^{4}$ Zink berfungsi untuk pertumbuhan dan perkembangan janin. Defisiensi zink selama kehamilan dapat menimbulkan berat badan lahir rendah, IUGR, kelahiran preterm serta komplikasi lainnya selama kehamilan. ${ }^{6}$

Vitamin A merupakan salah satu mikronutrien lainnya yang memiliki peranan penting bagi ibu hamil dan janin. ${ }^{7}$ Vitamin A berperan dalam ekspresi gen, pertumbuhan dan perkembangan janin, fungsi imun serta bone remodelling. Kekurangan konsumsi vitamin A selama kehamilan disinyalir memiliki korelasi positif dengan berat badan lahir serta durasi kehamilan. ${ }^{6}$ Asam folat berfungsi sebagai koenzim metabolisme asam amino dan sintesis asam nukleat. ${ }^{1}$ Defisiensi asam folat berdampak pada gangguan replikasi DNA dan pembelahan sel sehingga meningkatnya risiko bayi lahir prematur, berat bayi lahir rendah dan retardasi pertumbuhan fetal. ${ }^{8}$
Studi yang dilakukan oleh Czeizel et al pada tahun 2010 menunjukkan bahwa ada sedikit peningkatan pada rata-rata berat badan bayi saat dilahirkan setelah pemberian asam folat dosis tinggi selama kehamilan, namun akan didapat penurunan bermakna pada jumlah persalinan prematur. $^{9}$ Penelitian lain yang dilakukan oleh Fitranti et al pada tahun 2007 juga menunjukkan bahwa tingkat asupan asam folat dan zink mempengaruhi berat badan lahir. ${ }^{10}$ Penelitian yang dilakukan oleh Watanabe et al pada tahun 2008 menunjukkan hasil yang berbeda. Penelitian tersebut menunjukkan bahwa asam folat tidak menjadi indikator yang mempengaruhi berat badan lahir. ${ }^{11}$

Hal tersebut menunjukkan bahwa belum ada keseragaman hasil yang menunjukkan apakah asam folat, zink, dan vitamin A memiliki pengaruh terhadap berat badan lahir. Oleh karena itu perlu diteliti hubungan antara asupan asam folat, zink dan vitamin A ibu hamil trimester III terhadap berat badan lahir di kabupaten Padang Pariaman. Tujuan penelitian ini adalah untuk menentukan hubungan antara asupan asam folat, zink dan vitamin A ibu hamil trimester III di kabupaten Padang Pariaman.

\section{METODE}

Penelitian dilakukan di Kota Pariaman dari Juli 2011 sampai Desember 2013. Subjek dalam penelitian ini sebanyak 59 orang. Subjek merupakan ibu hamil yang melahirkan dengan bantuan Bidan yang telah bekerja sama dalam penelitian Prof. dr. Nur Indrawaty Lipoeto, M.Sc., Ph.D., Sp.GK dan kawankawan di kabupaten Padang Pariaman dari JuliSeptember 2011 yang memenuhi kriteria inklusi dan tidak memiliki kriteria eksklusi. Teknik pengambilan subjek adalah dengan simple random sampling. Instrument penelitian yang digunakan adalah kuesioner konsumsi makanan Food Frequency Quesionare (FFQ), timbangan untuk mengukur badan lahir bayi (merek Baby Scale) yang mempunyai ketelitian $0,1 \mathrm{~kg}$ dan kuesioner untuk pengisian identitas responden. Data yang diperoleh diolah secara komputerisasi dengan uji korelasi $p<0,05$. 


\section{HASIL dan PEMBAHASAN}

Tabel 1. Distribusi frekuensi berat badan lahir

\begin{tabular}{cccc}
\hline $\begin{array}{c}\text { Berat badan } \\
\text { lahir (gr) }\end{array}$ & Frekuensi & (\%) & $\begin{array}{c}\text { Rata-rata } \\
\text { BBL total (gr) }\end{array}$ \\
\hline$<3000$ & 8 & 13,56 & \\
$>3000$ & 51 & 86,44 & \\
\hline Total & $\mathbf{5 9}$ & $\mathbf{1 0 0}$ & $\mathbf{3 1 8 1 , 3 6}$ \\
\hline
\end{tabular}

Tabel 1 menunjukkan bahwa rata-rata berat lahir adalah 3181,36 gram, sedangkan untuk berat lahir $<3000$ terdapat 8 orang dan sisanya $>3000$ gram.

Tabel 2. Distribusi frekuensi asupan asam folat

\begin{tabular}{cccc}
\hline $\begin{array}{c}\text { Berat } \\
\text { Badan } \\
\text { Lahir }\end{array}$ & Frek & $\begin{array}{c}\text { Rata-rata } \\
\text { Konsumsi } \\
(\mathbf{u g})\end{array}$ & $\begin{array}{c}\text { Rata-rata asupan } \\
\text { total } \\
(\mathbf{u g})\end{array}$ \\
\hline $\mathbf{g r})$ & & & \\
$\geq 3000$ & 8 & 175,606 & \\
\hline Total & $\mathbf{5 9}$ & 368.9927 & \\
\hline
\end{tabular}

Tabel 2 menunjukan bahwa rata-rata asupan asam folat total 341,9525 ug, termasuk dibawah AKG (600 ug). Kelompok dengan berat lahir < 3000 asupan asam folatnya juga lebih rendah dibandingkan dengan asupan kelompok dengan berat lahir $>3000 \mathrm{gr}$.

Tabel 3. Distribusi frekuensi asupan zink

\begin{tabular}{|c|c|c|c|}
\hline $\begin{array}{c}\text { Berat } \\
\text { Badan } \\
\text { Lahir } \\
(\text { gr ) }\end{array}$ & Frek & $\begin{array}{l}\text { Rata-rata } \\
\text { Konsumsi } \\
\text { Zink (mg) }\end{array}$ & $\begin{array}{c}\text { Rata-rata asupan total } \\
(\mathrm{mg})\end{array}$ \\
\hline$<3000$ & 8 & 5,1 & \\
\hline$\geq 3000$ & 51 & 5,1 & \\
\hline Total & 59 & & 5,0727 \\
\hline
\end{tabular}

Berdasarkan Tabel 3 menunjukan bahwa ratarata asupan zink total 5,0727 $\mathrm{mg}$, termasuk dibawah AKG (11 mg). Kelompok dengan berat lahir < 3000 asupan zinknya sama dengan asupan kelompok dengan berat lahir $>3000 \mathrm{gr}$.

Tabel 4 menunjukan bahwa rata-rata asupan vitamin $A$ total $688,9300 \mathrm{RE}$, termasuk dibawah AKG (800 RE).
Tabel 4. Distribusi frekuensi asupan zink

\begin{tabular}{cccc}
\hline $\begin{array}{c}\text { Berat } \\
\text { Badan } \\
\text { Lahir } \\
\text { (gram) }\end{array}$ & Frek & $\begin{array}{c}\text { Rata-rata } \\
\text { Konsumsi } \\
\text { Vit A (RE) }\end{array}$ & $\begin{array}{c}\text { Rata-rata asupan } \\
\text { total(mg) }\end{array}$ \\
\hline$<3000$ & 8 & 669,0625 & \\
$\geq 3000$ & 51 & 686.9778 & \\
\hline Total & 59 & & 688,9300 \\
\hline
\end{tabular}

Kelompok dengan berat lahir < 3000 asupan vitamin A nya lebih rendah dengan asupan kelompok dengan berat lahir $>3000 \mathrm{gr}$.

Tabel 5. Hubungan asupan asam folat dan berat badan lahir

\begin{tabular}{lccc}
\hline & & $\mathbf{r}$ & $\mathbf{p}$ \\
\cline { 3 - 4 } Konsumsi & Berat & 0,131 & 0,161 \\
Asam & Badan & & \\
Folat & Lahir & & \\
\hline
\end{tabular}

Tabel 5 menunjukan bahwa hubungan konsumsi asam folat dengan berat badan lahir bayi menunjukkan kekuatan hubungan yang sangat lemah $(r=0,131)$ dan berpola positif, artinya semakin tinggi konsumsi asam folat maka semakin tinggi berat badan lahir bayi. Hasil uji statistik didapatkan tidak ada hubungan antara konsumsi asam folat dengan berat badan lahir $(p=0,161)$.

Tabel 6. Hubungan asupan zink dan berat badan lahir

\begin{tabular}{cccc}
\hline & & $\mathbf{r}$ & $\mathbf{p}$ \\
\cline { 3 - 3 } Konsumsi & Berat & $-0,084$ & 0,264 \\
& Badan & & \\
& Lahir & & \\
\hline
\end{tabular}

Tabel 6 menunjukan bahwa hubungan konsumsi zink dengan berat badan lahir bayi menunjukkan kekuatan hubungan yang sangat lemah $(r=-0,084)$ danberpola negatif, artinya semakin tinggi konsumsi zink maka semakin rendah berat badan lahir bayi. Hasil uji statistik didapatkan tidak ada hubungan antara konsumsi zink dengan berat badan lahir $(p=$ 0,264). 
Tabel 7. Hubungan asupan vitamin A dan berat badan lahir

\begin{tabular}{lccc}
\hline & & $\mathbf{r}$ & $\mathbf{p}$ \\
\cline { 3 - 4 } Konsumsi & Berat & 0,006 & 0,965 \\
& Badamin A & & \\
& Lahir & & \\
\hline
\end{tabular}

Tabel 7 menunjukkan hubungan konsumsi vitamin $A$ dengan berat badan lahir bayi kekuatan hubungan yang sangat lemah $(r=0,006)$ dan berpola positif, artinya semakin tinggi konsumsi vitamin A maka semakin tinggi berat badan lahir bayi. Hasil uji statistik didapatkan tidak ada hubungan antara konsumsi vitamin $A$ dengan berat badan lahir $(p=$ 0,965).

\section{KESIMPULAN}

Hasil analisis didapatkan bahwa tidak terdapat hubungan yang bermakna antara asupan asam folat, zink, dan vitamin A dengan berat badan lahir.

\section{DAFTAR PUSTAKA}

1. Scott J, Helen M. Outcome yang merugikan pada kehamilan: peranan folat dan vitamin B. Dalam : Michael JG,Barrie MM, Jhon MK, Lenore A, editor (penyunting). Gizi Kesehatan Masyarakat. Jakarta: EGC; 2005. hlm.348-54.

2. Kosim MS, Ari Y, Rizalya D, Gatot IS, Ali U. Buku ajar neonatologi. Jakarta: Badan Penerbit Ikatan Dokter Anak Indonesia; 2010.

3. Dinas Kesehatan Kota Pariaman. Profil kesehatan Kota Pariaman tahun 2008. Pariaman; 2008.
4. Arisman. Buku ajar ilmu gizi gizi dalam daur kehidupan. Jakarta: EGC; 2010. hlm. 3-21.

5. Cunningham FG, Norman FG, Kenneth JL, Larry CG III, Jhon CH, Katharine DW. Obstetri Williams (terjemahan). Jakarta: EGC; 2006. hlm. 763-851.

6. The Ministry of Health. Food and nutrition guidelines for healthy pregnant and breastfeeding women. Wellington: The Ministry of Health; 2006.

7. Yakoob, Mohammad Y, Khan, Yasir P, Zulfiqar AB. Maternal mineral and vitamin supplementation in pregnancy. Burden of Maternal Micronutrient Deficiencies and Evidence Base for Interventions. 2010;5(2).

8. Scholl OT,William JG. Folic acid: influence on the outcome of pregnancy. Am J Clin Nutr. 2000;71 (5): 1295-303.

9. Czeizel AE, Puhó EH, Langmar Z, Bánhidy ÁF. Possible association of folic acid supplementation during pregnancy with reduction of preterm birth: a population-based study. Eur J Obstet Gynecol Reprod Biol. 2010;148 (2):135-40.

10. Fitranti DY, Endang P. Hubungan pertambahan berat badan, kadar hemoglobin, dan tingkat asupan asam folat dan seng ibu hamil pada trimester II dan III dengan berat lahir bayi di puskesmas ngesrep dan pandanaran (skripsi). Semarang: Universitas Diponegoro; 2007.

11. Watanabe $H$, Fukuoka $H$, Sugiyama $T$, Nagai $Y$, Ogasawara K, Yoshiike. Dietary folate intake during pregnancy and birth weight in Japan. NEur $\mathrm{J}$ Nutr. 2008;47(6):341-7. 